\title{
Anatomical Description of the Liver, Hepatic Ligaments and Omenta in the Coypu (Myocastor coypus)
}

\author{
Descripción Anatómica del Hígado, Ligamentos hepáticos y Omentos en el Coipo (Myocastor coypus) \\ Pérez, W. \& Lima, M.
}

PÉREZ, W. \& LIMA, M. Anatomical description of the liver, hepatic ligaments and omenta in the coypu (Myocastor coypus). Int. J. Morphol., 25(1):61-64, 2007.

SUMMARY: The objective of this work is to give a complementary description of the hepatic lobulation, the hepatic ligaments and the omenta of the nutria. Thirty nutrias were studied by gross dissection. The liver of the nutria was divided into six lobules as follows: left lateral, left medial, quadrate, right medial, right lateral, and caudate lobes. The caudate lobe was divided into a papillary and a caudate process. A whole falciform ligament, extending as far as the navel, was found in all animals. This one was the only ligament that contained fat in between its sheets, and it was abundant in the umbilical part. The left triangular ligament had two parts. One of them was attached to the left lateral lobe of the liver and the other one to the left medial lobe. The right triangular ligament also was double. The lateral triangular ligaments where larger than the medial ones. The hepatorenal ligament it was attached to the right kidney and its ventral free border measured $3.0 \mathrm{~cm}$. The coronary ligament was always relatively well marked and was continuous with all the previous ligaments. The omenta were similar to those described for the rabbit but had more fat. The greater omentum united with the left sheet of the mesoduodenum and to the ascending mesocolon.

KEY WORDS: Anatomy; Liver; Hepatic ligaments; Omenta; Myocastor coypus.

\section{INTRODUCTION}

The coypu or nutria, Myocastor coypus (Molina, 1782 ) is a South American rodent that belongs to the suborder Hystricognathi, family Myocastoridae. (D'Elia, 1999).

Today it is found in all continents, living in swamps and fish ponds as a feral animal or raised in captivity for its fur. A demand for nutria fur developed in the early 19th century and has continued to the present. For this reason, the nutria has been introduced almost worldwide. Nutrias have also been hunted by people for meat (Woods et al., 1992). The nutrias are herbivorous. The diet consists largely of aquatic vegetation: stems, leaves, roots, and even bark (Woods et al.).

Because of the increase in number of captive animals it has become necessary to learn more about the biology of this species in order to be able to respond to questions concerning the health and breeding of these animals.

The anatomy of the liver, hepatic ligaments and omenta of the domestic mammals is well described in the classical literature (Barone, 1997, 2001). Within the order Rodentia most of the species have never been studied and a suitable nomenclature such as the Nomina Anatomica Veterinaria (NAV, 2005) has not been employed. The information available about the anatomy of the liver and the connecting peritoneum of rodents is scarce.

The only description found of the liver of the nutria (Wagner, 1963) divides it into three lobules: right, diaphragmatic or middle lobe and the left lobe and the only ligament observed by the author was the falciform ligament. Wagner described the gall bladder, the extrahepatic biliary ducts and the pancreas. With respect to the pancreas he does not make any reference about its exact location within the connecting peritoneum. Also he didn't describe the omenta. In the rabbit the peritoneal folds have recently been described including the hepatic ligaments and the omenta (Pérez et al., 2005).

The objective of this work is to describe the hepatic lobulation, the hepatic ligaments, and the omenta of the nutria. 


\section{MATERIAL AND METHOD}

Thirty adult nutrias, 25 females and 5 males, have been studied. The age of the animals spanned 2 years and they weighed between 5 and $6 \mathrm{~kg}$. The animals were bought from a breeding farm licensed by the Ministry of Livestock and Agriculture. They were killed by an overdose of sodium thiopental administered intravenously. Twenty five animals were dissected fresh and the other five were previously fixed by arterial perfusion with $10 \%$ formalin. The NAV, 2005 was used.

\section{RESULTS}

The liver of the nutria occupied the hole of the cranial intrathoracic part of the abdominal cavity, was light brown in color and the average weight was $110.6 \mathrm{~g}$.

A diaphragmatic and a visceral face were recognized, separated by a dorsal and a ventral border that were joined by two lateral borders. The diaphragmatic face was smooth and convex. The visceral face (Fig.1) had the porta hepatis, and apart from being closely with the stomach it had contact with both kidneys. The cranial extremity of the left kidney was covered by the left lobe of the liver.

The portion of the liver situated to the left side of the round ligament was the left lobe. The portion that was to the right side of the gall bladder and porta hepatis was the right lobe. Ventral to the porta hepatis, the fissure of the round ligament and the fossa of the gall bladder demarcated the quadrate lobe. The gall bladder was found in between the quadrate and right medial lobes. The caudate lobe was found dorsally, divided into the papillary and caudate processes. The papillary process was lodged near the lesser curvature of the stomach at the vestibule of the omental bursae.

The left and right lobes were subdivided into medial and lateral parts. So the liver was divided into six lobes (Fig. 2): left lateral, left medial, quadrate, right medial, right lateral, and caudate lobes, the latter one subdivided into a caudate and a papillary process.

A whole falciform ligament, extending as far as the navel, was found in all animals. It was the only ligament that had fat between its sheets, which was abundant in the umbilical part and was non existent in its diaphragmatic part. The falciform ligament had a maximum width of $3.0 \mathrm{~cm}$ at the middle of the umbilical part. In its free border the presence of the thick round ligament was outstanding.

The left triangular ligament was composed of two parts. One part was attached to the left lateral lobe of the liver and the other one to the left medial lobe. The average length of the free border of both parts was 4.3 and $3.4 \mathrm{~cm}$, respectively. The right triangular ligament also was double. The portion directed towards the right lateral measured $3.9 \mathrm{~cm}$ in its free border while the one attached to the right medial lobe measured $3.2 \mathrm{~cm}$. The hepatorenal ligament was attached to the right kidney and measured $3.0 \mathrm{~cm}$ in its free ventral border (Fig. 2. black arrows). In some animals also had a parietal insertion on the parietal peritoneum medial to the kidney.

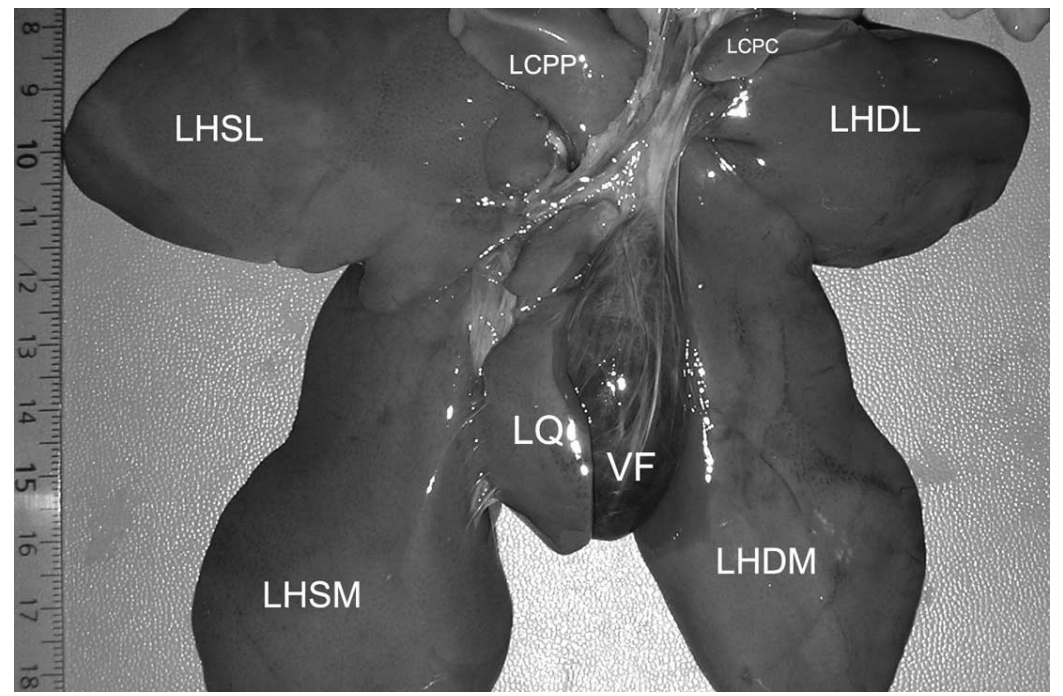

Fig. 1. Facies visceralis of the liver of the nutria. LCPC: Lobus caudatus, Processus caudatus; LCPP: Lobus caudatus, Processus papillaris; LQ: Lobus quadratus; LHSL: Lobus hepatis sinister lateralis; LHSM: Lobus hepatis sinister medialis; LHDL: Lobus hepatis dexter lateralis; LHDM: Lobus hepatis dexter medialis; VF: Vesica fellea.
The coronary ligament which attached the liver to the diaphragm bordering the caudal vena cava, was always relatively well marked and had continuity with all of the above mentioned ligaments.

The greater omentum (Fig. 3) was attached to the whole length of the transverse colon. Adipose tissue was abundant in the most fat animals and was less abundant in the most slim ones. The adipose tissue was found irregularly and most frequently distributed at the bottom and borders of the omental bursa as well as near the greater curvature of the stomach. Most of the greater omentum was found on the left side, sometimes part of it was to the right and was never unfolded between the intestinal coils and the ventral wall of the abdomen. Never did the caudal part of the burse reached a transverse plane along the umbilicus. 


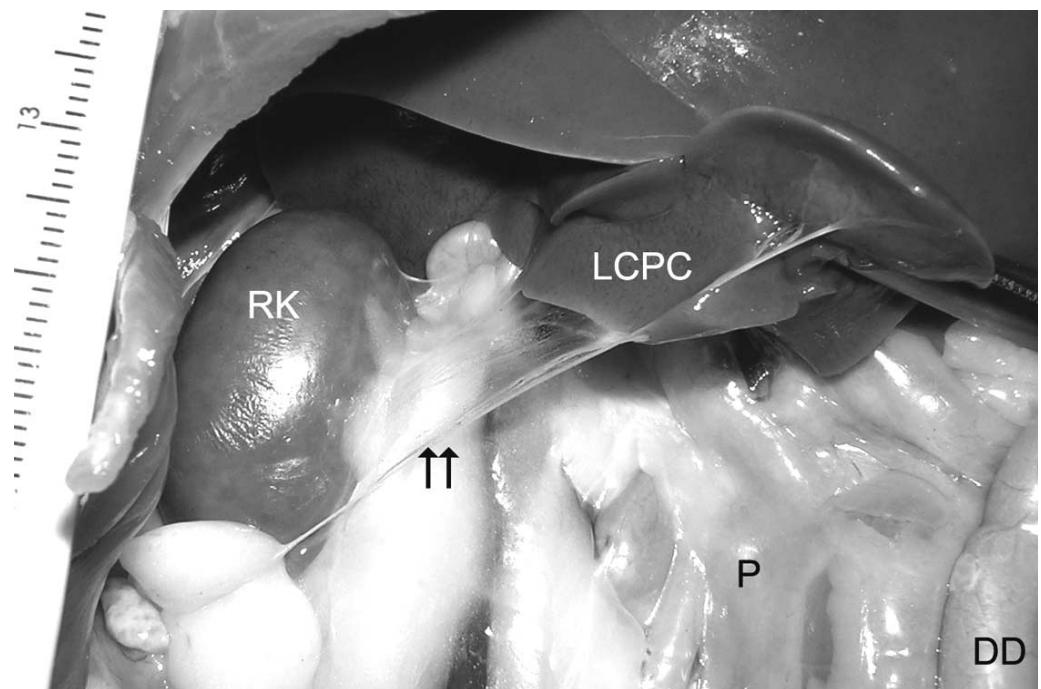

Fig. 2. Right ventral view, Black arrows: Hepatorenal ligament; RK: Right kidney; LCPC: Lobus caudatus, Processus caudatus; P: Pancreas; DD: Descending duodenum.

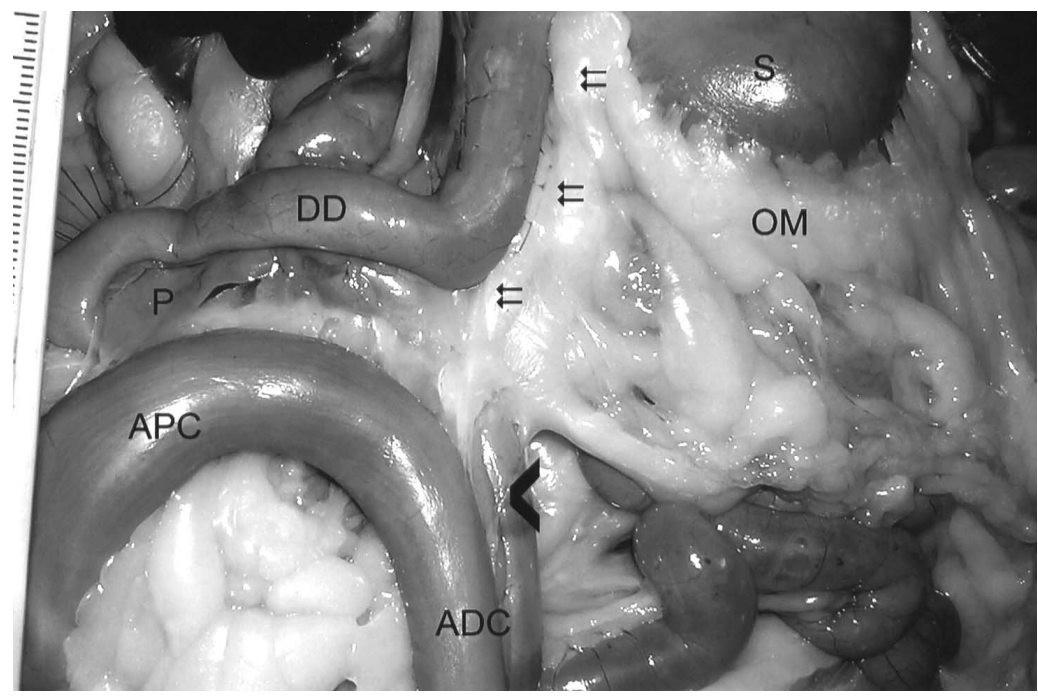

Fig. 3. Ventral view of the stomach, omenta and intestine. S: Stomach; DD: Descending duodenum; P: Pancreas; OM: Omentum majus; APC: Ansa proximalis coli; ADC: Ansa distalis coli; Small black arrows: Right border of the greater omentum joined to the left sheet of the mesoduodenum; Large black arrow head towards left side: Greater omentum united with the ascending mesocolon of the Ansa distalis coli.

The omental foramen had a cranio-caudal length of $3.5 \mathrm{~cm}$ and communicated the vestibule of the omental bursa with the rest of the peritoneal cavity.

The entrance to the caudal recess of the omental bursa was a great and a constant opening. The average length of the extended bursa from the greater curvature of the stomach up to the bottom of the omental bursa was $15 \mathrm{~cm}$.

The right border of the omental burse was attached cranially to the left sheet of the mesoduodenum (Fig. 3, small black arrows), and more caudally to the mesocolon that united both parts of the distal ansa of the ascending colon (Fig. 3, large black arrow head towards left side).

The deep wall of the greater omentum housed cranially the left lobe of the pancreas. This lobe was more or less disseminated.

The lesser omentum did not have fat except along the bile duct (ductus choledochus) near the duodenum.

\section{DISCUSSION}

Data of the weight of the liver of 200 to $219 \mathrm{~g}$ given by Wagner do not coincide with our findings, where the average weight was $110.6 \mathrm{~g}$.

Analyzing the description and the drawing of the liver and its division into three lobes done by the same author we see that he includes within the right lobe the right lateral lobe and the caudate and papillary processes of the caudate lobe. The middle lobe described by Wagner corresponds to the right and left medial lobes and the quadrate lobe. According to Wagner the middle lobe was the largest, and here we coincide since the right and left lobes and the quadrate lobe represent the largest part of the organ. The left lobe cited by Wagner corresponds to the left lateral lobe.

The only hepatic ligament mentioned for the nutria was the falciform (Wagner). This ligament was complete in the nutria. In the case of the rabbit this ligament was incomplete and the most developed part was the one that reached the diaphragm. As in the nutria this part did not have fat. A whole falciform ligament, extending as far as the navel, was found in three of eighteen rabbits (Pérez et al.). It was remarkable the presence of the double triangular ligaments, one for each part of the left and right lobes, and that the lateral triangular ligaments were larger than the medial ones. The left triangular ligaments were larger than the right ones. Also the left triangular ligament was the most developed in the rabbit and there were only two ligaments and not four as in the nutria (Pérez et al. ). 
The hepatorenal ligament it was attached to the right kidney in the nutria and in some animals also had a parietal insertion. The hepatorenal ligament of the rabbit is more complex and has a long parietal insertion. The lesser omentum was quite similar to the one described in the rabbit (Pérez et al.).

The omental foramen and the entrance to the caudal recess were much wider than in the rabbit. In equines entrapment of jejunum (Turner et al., 1984) or ascending colon (Segura et al., 1999; Marien, 1999) in the omental foramen is a frequent cause of colic. The fact that the foramen is so wide can, in theory, predispose to these type of hernia in the nutria.

The greater omentum differs with the description given for that of the rabbit (Pérez et al.) in the attachment of the right border to the left sheet of the mesoduodenum and cranial part of the mesocolon of the distal ansa of the ascending colon. The situation was similar to that of the rabbit.

The greater omentum probably folds back secondary to the mesoduodenum and ascending mesocolon in the course of prenatal development. The time at which this and other adhesions form between the mesos of the intestines requires the study of the different prenatal developmental fases undergone in the foetus.

ACKNOWLEDGEMENTS: We thank Agronomist Sebastián Moure owner of the breeding farm which sold the nutrias to us.

PÉREZ, W. \& LIMA, M. Descripción anatómica del hígado, ligamentos hepáticos y mentos en el conejo (Myocastor coypus). Int. J. Morphol., 25(1):61-64, 2007.

RESUMEN: El objetivo de este trabajo es complementar las descripciones de la lobulación hepática, los ligamentos hepáticos y los omentos de la nutria. Treinta nutrias fueron estudiadas mediante disección simple. El hígado de la nutria estaba dividido en seis lóbulos: lóbulos lateral izquierdo, medial izquierdo, cuadrado, medial derecho, lateral derecho y caudado. El lóbulo caudado estaba dividido en proceso papilar y proceso caudado. Un ligamento falciforme completo, extendido hasta el ombligo, fue hallado en todos los animales. Este era el único ligamento que tenía grasa entre sus hojas, la cual era abundante en la parte umbilical. El ligamento triangular izquierdo estaba compuesto por dos partes. Una parte se fijaba al lóbulo lateral izquierdo y la otra al lóbulo medial izquierdo del hígado. El ligamento triangular derecho también era doble. Los ligamentos triangulares laterales eran más grandes que los mediales. El ligamento hepatorrenal estaba unido al riñón derecho y medía $3,0 \mathrm{~cm}$ en su borde libre ventral. El ligamento coronario era siempre relativamente marcado y se continuaba con todos los ligamentos anteriores. Los omentos eran similares a los descritos para el conejo pero más cargados de grasa. El omento mayor se unía a la hoja izquierda del mesoduodeno y al mesocolon ascendente.

PALABRAS CLAVE: Anatomía; Hígado; Ligamentos hepáticos; Omentos; Myocastor coypus.

\section{REFERENCES}

Barone, R. Anatomie comparée des mammiféeres domestiques. Splanchnologie I. Appareil digestif, appareil respiratoire. $3^{\mathrm{a}}$ ed. Paris, Vigot Fréres, 1997. V. 3.

Barone, R. Anatomie comparée des mammiféres domestiques. Splanchnologie II. Appareil urogénital, foetus et ses annexes, péritoine et topographie abdominale, $3^{\mathrm{a}}$ ed. Paris, Vigot Fréres, 2001. V. 4.

D'Elia, G. Myocastor coypus (On-line), Animal Diversity Web. 1999. http://animaldiversity.ummz.umich.edu/site/accounts/ information/Myocastor_coypus.html.

Marien, T. Lateromedial incarceration of the large colon through the foramen omentale (Epiploic foramen) in a horse. Vlaams Diergeneeskundig Tijdschrift, 68(4)188-90, 1999.

Nomina Anatomica Veterinaria. $5^{\mathrm{a}}$ ed. Prepared by the International Committee on Veterinary Gross Anatomical Nomenclature (I.C.V.G.A.N.) Knoxville, TN (U.S.A.) 2003. Published, 2005. http://www.wava-amav.org/Downloads/nav_2005.pdf

Pérez, W.; Möller, R. \& Martin, E. Peritoneal Folds of the Rabbit (Oryctolagus cuniculus). Anat. Histol. Embryol.,34(3):167-70, 2005.
Segura, D.; Garzon, N.; Nomen, C.; Prades, M. \& Valls, S. Entrapment of large colon through the epiploic foramen in a horse. Equine Veterinary Education, 11(5):227-8, 1999.

Turner, T. A.; Adams, S. B. \& White, N. A. Small intestine incarceration through the epiploic foramen of the horse. J. Am. Vet. Med. Assoc., 184 (6):731-4, 1984.

Wagner, J. A. Gross and microscopic anatomy of the digestive system of the nutria, Myocastor coypu bonariensis (Geoffroy). J. of Morphol., 112:319-33, 1963.

Woods, C. A.; Contreras, L.; Willner Chapman, G. \& Whidden, H. P. Myocastor coypus. Mammalian Species, 398:1-8, 1992.

Correspondence to:

Dr. William Pérez

Área de Anatomía, Facultad de Veterinaria,

Received: 12-11-2006

A. Lasplaces 1550, 11600

Montevideo - URUGUAY

Email: williamperez13@hotmail.com 